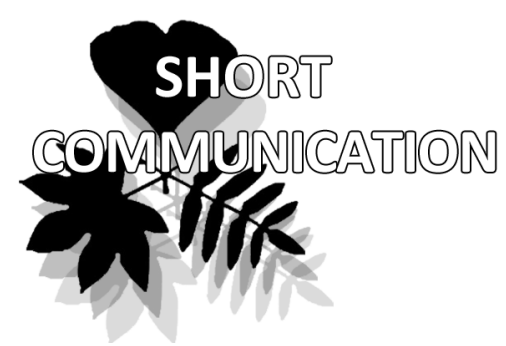

\title{
Portrayal of Allium spurium G. Don (Amaryllidaceae) from the border area of China and North Korea: a putative unrecorded species in the Korean Peninsula
}

Hyeok Jae Choi

Hyeok Jae Choi

e-mail: hjchoi1975@changwon.ac.kr

Department of Biology and Chemistry, Changwon National University, Gyeongnam 641-773, Korea

Manuscript received: 19.06.2015 Review completed: 07.08.2015 Accepted for publication: 12.08.2015 Published online: 18.08.2015

\begin{abstract}
A B S T R A C T
Here I report a little-known Allium species from the border area of China and North Korea. This taxon, $A$. spurium $\mathrm{G}$. Don is occasionally confused with $A$. spirale Willd. because of its more or less similar growth habit, but the most distinctive characters include narrower leaf blades and rhomboid scapes in cross-section. In addition, $A$. spurium is recognized as tetraploid species, whereas $A$. spirale proved to be diploid. Detailed photographs of $A$. spurium are provided together with complete descriptions including information on nomenclatural types, synonymy, distributions and specimens examined.
\end{abstract}

K e y w o r d s : Amaryllidace, Allium spurium, chromosome number, morphology, northeastern China

\section{P E 3 Ю M E}

Чои X.A. Allium spurium G. Don (Amaryllidaceae) из пограничной обмасти Китая и Северной Кореи: преАпомагаемый неучтенный виА на Корейском полуострове. Сообщается о находке малоизвестного виАа Allium из приграничной области Китая и Северной Кореи. ВиА мука Allium spurium G. Don иногда ошибочно принимают за Allium spirale Willd. из-за похожего габитуса, не принимая во внимание его отличительные признаки, такие как узкие мистовые пластинки и ромбовидный стебель в поперечном сечении. Кроме того, A. spurium - тетраплоил, тогда как Allium spirale - диплоид.

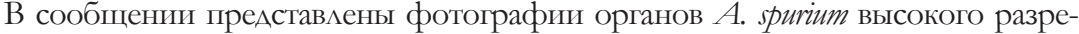
шения и его полное описание, а также информация о номенклатурных типах, синонимах, распространении и исследуемых образцах.

$\boldsymbol{К}_{\boldsymbol{\Lambda}}$ юче в в е с $\mathbf{\Lambda}$ ов а: Amaryllidace, Allium spurium, число хромосом, морфология, северо-восточный Китай
The genus Allium (Amaryllidacea) in Korea and northeastern China has been recently revised by Choi \& Oh (2011). Compared with the Flora of China (Xu \& Kamelin 2000), however, about ten taxa reported occurring in the north-eastern Chinese provinces of Heilongiiang, Jilin and Liaoning were excluded in Choi \& Oh (2011) because of inadequate material seen in the field or in herbaria. During my visit to the Korea National Herbarium $(\mathrm{KH})$ I had reexamined all Allium collections including living plants. As a result, I newly identified another little-known Allium species from the north-eastern China in addition to Choi \& Oh (2011). This taxon, A. spurium G. Don, is a member of sect. Rhizirideum G. Don ex Koch., and known to occur from Mongolia to Russian Far East passing through northeastern China (Xu \& Kamelin 2000). Although A. spurium is not reported in the Korean Peninsula up to the present, I expect this taxon to grow in the Korean Peninsula also as the collection sites for the materials examined are located the border area of China (Province Jilin) and North Korea (Fig. 1). Detailed photographs of $A$. spurium are provided together with complete descriptions including information on nomenclatural types, synonymy, chromosome number,

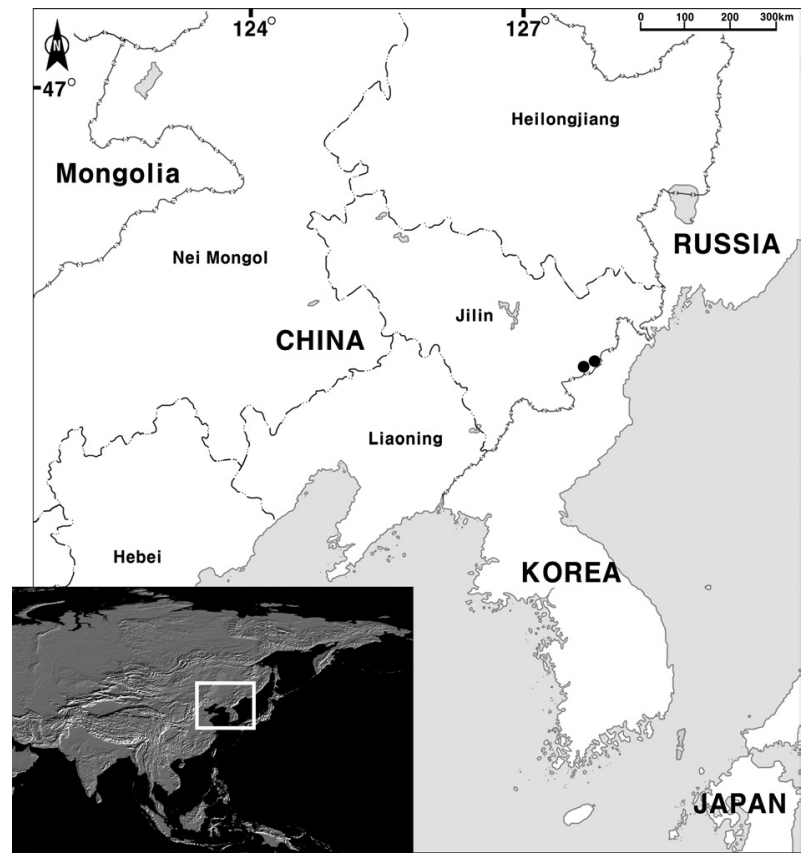

Figure 1 Collection sites (black circles) of Allium spurium examined in this study 

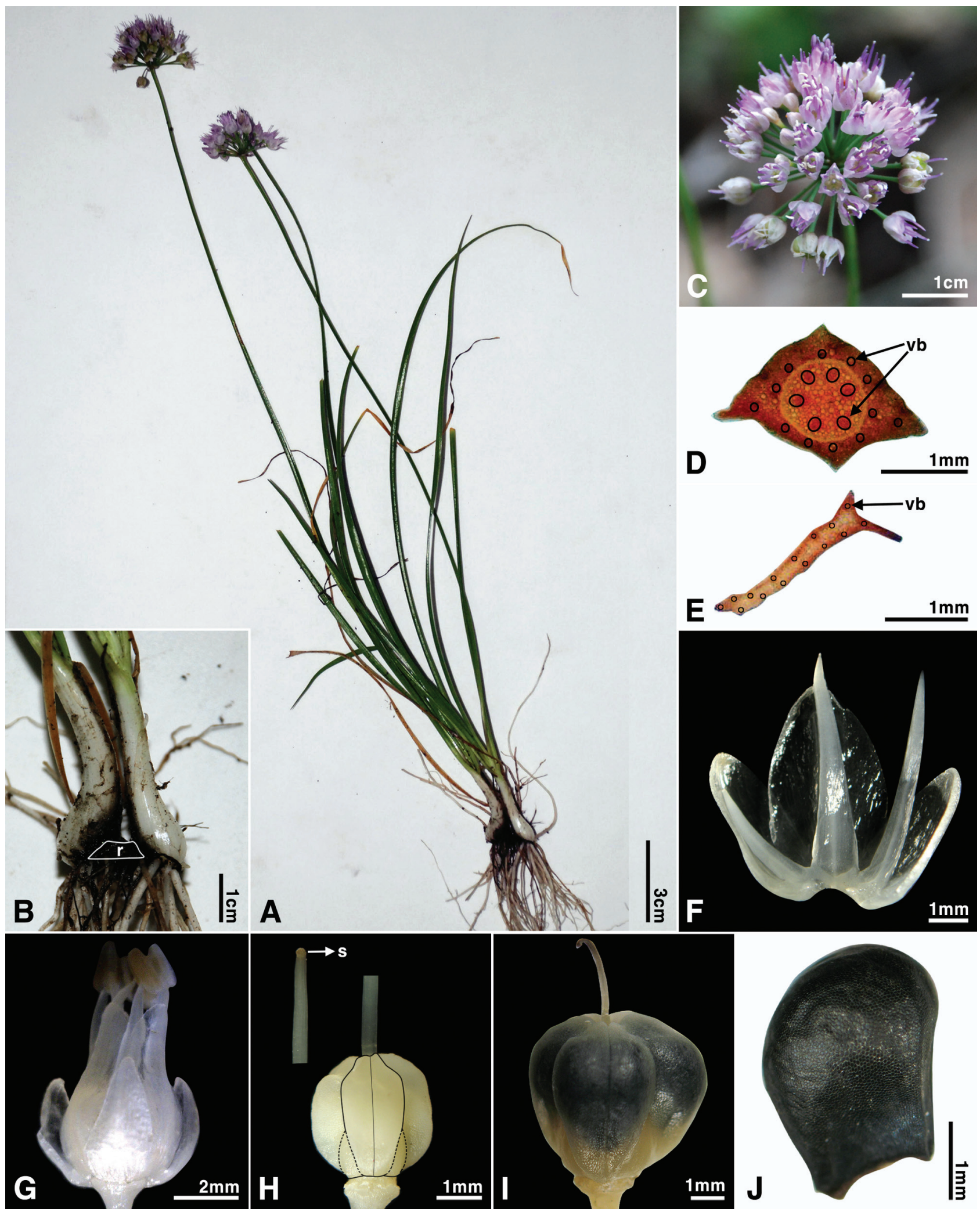

Figure 2 Allium spurium. A. Habit; B. Underground structure (r: rhizome); C. Inflorescence; D. Shape of scape in cross section (vb: vascular bundles); E. Shape of leaf in cross section (vb: vascular bundle); F. Tepal and filament arrangement; G. Flower; H. Pistil (s; stigma); I. Capsule; J. Seed.

distributions and specimens examined. Also, a key to species of Allium sect. Rhizirideum in Korea and north-eastern China are complemented from Choi \& Oh (2011). Methodology for morphological and cytological characters in this study followed Choi \& Oh (2011).

\section{Taxonomic treatment}

Allium spurium G. Don, Mem. Wern. Nat. Hist. Soc. 6: 59, 1827 (Fig. 2).

Type: Siberia (location in doubt). Type specimen not designated (protologue) 
= A. saxicola Kitag., Rep. Inst. Sci. Res. Manch. 2: 288, 1938. Type: China. Prov. Fengtien (Liaoning), in lapidosis circa Laohutan, 30 Aug. 1930, M. Kitagawa s.n. (holotype: TI).

=A. dauricum N. Friesen, Fl. Sibir. (Arac.-Orchidac.): 58, 1987. Type: Russia. Transbaicalia Orientalis, pagum Kyra, in valle fluvii Bukukun, in prato substepposo, 31 Aug. 1964, G. Peschkova et L. Ovczinnicova s.n. (holotype: LE!; isotype: NSK).

Description: Herbs hermaphroditic. Rhizomes horizontally elongated, thick (up to $5 \mathrm{~mm}$ ), 5-20 mm long. Bulbs usually paired, cylindrically conical, without bulbels, 5-15 mm in diam.; tunics membranous, smooth, whitish gray. Leaves 2-8; leaf sheaths not exposed above ground, 2-4 cm high, non-striped; leaf blades ascending, straight, flat, papery, usually glossy, narrowly linear, $15-30 \mathrm{~cm} \times 1.5-4 \mathrm{~mm}$, with 2 rows of vascular bundles and solid in cross-section, acute to gradually attenuate at apex. Scapes drooping before flowering, rhomboid and solid in cross-section, $10-40 \mathrm{~cm} \times$ $1.5-2.5 \mathrm{~mm}$. Inflorescences umbellate, hemigolbose, 20-40 $\times 25-45 \mathrm{~mm}, 22-55$ flowered; pedicels terete, subequal in length, 6-15 mm long, thinner than the scapes; bracts 3-5 $\mathrm{mm}$ long. Flowers bisexual; perianth campanulate, pinkish to reddish violet; inner tepals longer than outer ones, ovately elliptical, obtuse at apex, 5-5.5 × 2-3.2 mm; outer tepals ovately elliptical, obtuse at apex, 4-4.2 $\times 2-2.3 \mathrm{~mm}$; filaments exserted, 4-8 $\mathrm{mm}$ long, entire at margin; anthers elliptical, reddish, 1.7-2 mm long; ovary obovoid, reddish green, without appendages, $2.5-3 \times 2.2-2.5 \mathrm{~mm}$, ovules 2 per locule; style terete, exserted; stigma smooth to slightly capitate. Capsules cordiform, trigonous, 4.8-5.1 $\times$ 4.5-5 $\mathrm{mm}$. Seeds oval, semi-circular in cross-section, $2.8-3.2 \times$ $2-2.3 \mathrm{~mm}$.

Chromosome number: $2 \mathrm{n}=32$ (Fig. 3; Friesen 1987; Xu \& Kamelin 2000).

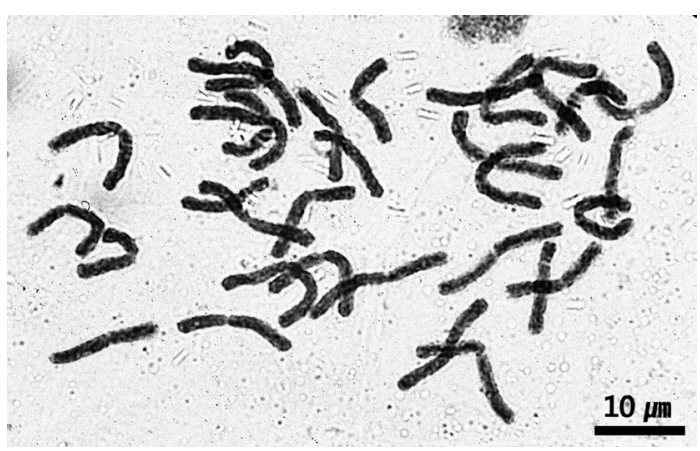

Figure 3 Somatic chromosomes of Allium spurium

Distribution and habitat: Russia (Far East), Mongolia, northeastern China (Heilongjiang; Jilin; Liaoning; Nei Mongol). In meadows, steppes, and dry slopes of mountains.

Phenology: Flowering from July to August.

Notes: Allium spurium is occasionally confused with A. spirale Willd. because of its more or less similar growth habit, but the most distinctive characters include narrower leaf blades (Fig. 2A, 2E) and rhomboid scapes in cross-section (Fig. 2D). In addition, $A$. spurium is recognized as tetraploid $(2 \mathrm{n}=4 \mathrm{x}=32)$ species (Fig. 3; Friesen 1987; Xu \& Kamelin
2000), whereas $A$. spirale proved to be diploid $(2 \mathrm{n}=2 \mathrm{x}=16$; Choi \& Oh 2010).

Specimens examined: CHINA: JILIN - Helong, 8 Sep. 2007, H.J. Choi s.n. (KH); Helong, 9 Sep. 2007, H.J. Choi s.n. $(\mathrm{KH})$.

\section{Key to the species of Allium sect. Rhizirideum in north-eastern China and Korea}

1. Leaf sheaths buried under ground; leaf blades leathery, lustrous; perianths campanulate; inner tepals ovate-elliptical; inner filaments entire at margin.

2. Leaf blades $1.5-4 \mathrm{~mm}$ wide; scapes rhomboid in crosssection $(2 \mathrm{n}=32)$

A. spurium

2. Leaf blades 4-10 mm wide; scapes clearly flattenedwinged in cross-section $(2 \mathrm{n}=16)$

A. spirale

1. Leaf sheaths exposed above ground; leaf blades fleshy, glaucous; perianths radially spreading; inner tepals elliptical; inner filaments entire or toothed at margin.

3. Leaf blades $2.8-4.5 \mathrm{~mm}$ wide; scapes subterete in crosssection, $11.7-20.5 \mathrm{~mm}$ long; inner tepals $3.5-4.7 \mathrm{~mm}$ long, 1-1.8 mm wide; outer tepals 3.4-4 mm long, $0.8-1.2 \mathrm{~mm}$ wide; filaments non-exserted, 3.8-4.8 $\mathrm{mm}$ long; capsules 3.5-3.7 $\mathrm{mm}$ long, $3.6-4 \mathrm{~mm}$ wide; seeds $2-2.2 \mathrm{~mm}$ long, $1.3-1.5 \mathrm{~mm}$ wide; flowering from May to August $(2 \mathrm{n}=16) \ldots$ A. minus

3. Leaf blades 3.8-15 mm wide; scapes subterete to rhomboid in cross-section, $23.4-70 \mathrm{~mm}$ long; inner tepals 6-7 $\mathrm{mm}$ long, $2.5-3.5 \mathrm{~mm}$ wide; outer tepals $4.5-5.5 \mathrm{~mm}$ long, 2-2.7 mm wide; filaments exserted, $6.2-11.0 \mathrm{~mm}$ long; capsules $4.5-5.6 \mathrm{~mm}$ long, $4.5-5.8 \mathrm{~mm}$ wide; seeds $3-3.8 \mathrm{~mm}$ long, 2.2-2.6 $\mathrm{mm}$ wide; flowering from August to October $(2 \mathrm{n}=32)$.

4. Rhizomes oblique; pedicels not slender; perianths reddish pink; inner filaments narrowly triangular, entire at margin; inner tepals 3-3.4 mm wide; anthers reddish; ovaries 3-3.5 mm wide A. senescens

4. Rhizomes horizontal; pedicels slender; perianths pale pink; inner filaments subulate, entire or 2-toothed at margin; inner tepals $2.5-3 \mathrm{~mm}$ wide; anthers yellowish; ovaries 2.2-2.6 $\mathrm{mm}$ wide A. pseudosenescens

\section{ACKNOWLEDGEMENTS}

This research was financially supported by Changwon National University in 2014-2015.

\section{LITERATURE CITED}

Choi, H.J. \& B.U. Oh 2010. A new species and a new combination of Allium sect. Rhizirideum (Alliaceae) from northeastern China and Korea. Brittonia 62:199-205.

Choi, H.J. \& B.U. Oh 2011. A partial revision of Allium (Amaryllidaceae) in Korea and north-eastern China. Botanical Journal of the Linnean Society 167:153-211.

Friesen, N. 1987. The Genera Allium L. and Caloscordum Herbert. In: Flora of Siberia, vol. 4, (L. Malyshev \& G. Peshkova, eds.), pp. 55-97, Nauka Sib. Otdel., Novosibirsk.

Xu, J-M. \& R.V. Kamelin 2000. Allium L. In: Flora of China, vol. 24, (Z-Y. Wu \& P. H. Raven, eds.), pp. 165-202, Science Press and Missouri Botanical Garden Press, Beijing and St. Louis. 